SECTION 21. Pedagogy. Psychology. Innovations in the field of education.

Sofronova Larisa Anatolyevna

postgraduate student

«Chuvash state pedagogical University

name after I.Ya. Yakovlev», Cheboksary, Russia

\title{
FORMATION OF RESEARCH COMPETENCES OF PUPILS OF THE LAST CLASSES
}

In modern conditions was in need of personality, able to self-realization in various areas of a science: educational, creative, economic, administrative and other In this regard, in educational practice, there is a task of formation at pupils of readiness for the implementation of research activities.

Key words: school, science competence.

\section{ФОРМИРОВАНИЕ ИССЛЕДОВАТЕЛЬСКОЙ КОМПЕТЕНЦИИ УЧАЩИХСЯ СТАРШИХ КЛАССОВ}

В современных условиях возникла острая потребность в личности, способной $\kappa$ самореализачии в различных областях науки: образовательной, творческой, экономической, управленческой и др. В связи с этим в образовательной практике возникает задача формирования $y$ старшеклассников готовности $\kappa$ осуществлению исследовательской деятельности.

Ключевые слова: школа, наука, компетенции.

В настоящее время данная деятельность рассматривается как фактор индивидуального самосовершенствования субъекта, направлен на развитие навыков самостоятельного овладения знаниями и творческого восприятия современных наук, обеспечивающая готовность к вхождению в мир научных исследований, что в свою очередь способствует формированию исследовательской компетенции учащихся. От уровня сформированности которой зависит успешность осуществления профессиональной деятельности.

При организации исследовательской деятельности необходимо ориентироваться на цели и результаты включения школьников в данный вид деятельности. Главными целями при этом являются:

- приобретение навыка решения исследовательских задач, развитие способности строить достоверные представления об окружающем мире, закономерностях протекания различных процессов, явлений;

- создание познавательно-исследовательской базы;

- развитие способностей учащихся к рефлексии своей деятельности, умению анализировать и обобщать [5]; 
- обеспечение психологической готовности к вхождению в мир научных исследований новых поколений ученых.

Результат исследовательской деятельности учащихся старших классов состоит в формировании исследовательской компетенции. Таким образом, можно говорить о том, что только в процессе деятельности может формироваться компетенция. В частности, исследовательская компетенция, которая напрямую связана с умением найти ответ на исследовательскую задачу.

Проблему формирования исследовательской компетенции учащихся старших классов исследовали многие отечественные и зарубежные ученые.

Сам термин «компетенция» происходит от латинского «competentia» - «согласованность частей». Смысл данного понятия обозначен в трудах многих ученых.

В.Д. Шадриков рассматривает компетенцию как «готовность ученика использовать усвоенные знания, учебные умения и навыки, а также способы деятельности в жизни для решения теоретических и практических задач» [6].

Компетенция определяется как индивидуальная характеристика личности (А.К. Маркова), как сфера приложения знаний, умений и навыков (В.М. Монахова, А.И. Нижникова). Так Ю.Г. Татур отмечает, что совокупность компетенций составляет модель выпускника школы [4]. В своем научном исследовании И.А. Зимняя выделяет три компетенции: компетенции, относящиеся к личности выпускника; к взаимодействию с другими людьми; к деятельности [3].

Анализ подходов к определению понятия «компетенция», а также утверждение В.И. Байденко в том, что «... результаты образования - это конкретные достижения выпускников, выражающиеся в знаниях, умениях и навыках, способностях, компетенциях, и которые описывают, что должен будет в состоянии делать выпускник по завершении всей или части образовательной программы» [1].

C нашей точки зрения более приемлемое определение исследовательской компетенции будет следующее. Исследовательская компетенция - это общая готовность личности к самостоятельному осуществлению исследовательской деятельности на основе сформированных знаний, умений, навыков и имеющегося опыта при решении проблемы. Т. е. она базируется на умениях ставить цель работы, выдвигать гипотезы, правильно организовывать собственную деятельность, планировать и проводить исследования в определенной области науки. В ходе выполнения работы у школьников формируются практические навыки, навыки оформления результатов работы такого рода, формулировки соответствующих выводов. Учащиеся приобретают умения анализировать, осуществлять рефлексию, самооценку своей поисковой деятельности. 
В педагогической науке не существует общепринятых алгоритмов и схем, по которым формируется исследовательская компетенция учащихся старших классов. Она не возникает сама по себе, а требует времени и поэтапной организации.

Л.М. Репета в своем научном труде выделяет следующие этапы формирования исследовательской компетенции учащихся: подготовительный (осмысление); ориентационный (осознание); формирующий (исследование, результат, коррекция).

Первый этап - подготовительный (осмысление). Целью данного этапа является подготовка обучающихся к аналитической деятельности и рефлексии имеющегося опыта, т. е. его осмыслению [4]. На этапе осмысления создаются возможности для развития познавательной активности учащихся через традиционные формы обучения: занятия, экскурсии, наблюдения, где ставились вопросы проблемного характера, создавались проблемные ситуации.

Второй этап - ориентационный (осознание). Этап осознания характеризуется формированием исследовательской компетенции у учащихся важным становится создание условий для исследовательской деятельности. При этом ведется изучение мотивов и предпочтений учащихся старших классов общеобразовательной школы, выявление интересных тем и проблем для введения исследовательской деятельности.

Анализ психолого-педагогической литературы показал, что исследовательская компетенция формируется в деятельности и может быть реализована в том случае, когда субъект занимает активную исследовательскую позицию по отношению к деятельности, имеет мотивацию к ней. На втором этапе с целью формирования исследовательской компетенции учащихся старших классов Л.М. Репета предлагает применение такого способа как самопрограммирование, которое предполагает материализацию собственного прогноза о возможном совершенствовании своей исследовательской компетенции [4]. Средством реализации способа самопрограммирования являлось построение научного понятия «Я - концепции», связана с именами Р. Бернса, А. Маслоу, Р. Роджерса. Так, по мнению Р. Бернса, «Я-концепция» определяет не просто то, что собой представляет индивид, но и то, что он о себе думает, как смотрит на свое деятельностное начало и возможности развития в будущем [2].

Третий этап - деятельностно-практический (исследовательский). Основной целью данного этапа является формирование исследовательской компетенции учащихся [4]. Пройдя первый и второй этапы на пути формирования исследовательской компетенции, учащиеся могут самостоятельно решать проблемы исследовательского характера, выдвигать гипотезу, ставить задачи, предлагать пути решения, использовать альтернативные пути поиска информации. 
С целью актуализации имеющихся знаний в процессе познания, учетом особенностей старшеклассников используются эффективные формы и методы работы по активизации исследовательской деятельности учащихся, а именно использование метода проектов, организация дискуссий при защите результатов исследования, проведение «Исследовательского турнира» как активной формы обучения.

Эффективность экспериментальной работы по формированию исследовательской компетенции учащихся старших классов определяется следующими педагогическими условиями:

- поэтапное формирование исследовательской компетенции, внутренней мотивации старшеклассников;

- создание образовательной среды, заключающееся в самостоятельном выборе учащимися формы и способов, уровня сложности работы, которые наполнены для них личностным смыслом;

- включение обучающихся в качестве субъектов в различные формы и виды исследовательской деятельности, при этом они являются равноправными участниками диалога с учителем.

Проведенная в исследуемом направлении экспериментальная работа показала, что реализация выявленных педагогических условий способствует поэтапному совершенствованию исследовательских компетенций учащихся старших классов, проявляющаяся в умении самостоятельно формулировать цели, планировать собственную деятельность или с другими учениками, применять знания, полученные из разных источников, выдвигать гипотезу, предлагать результат деятельности в различных формах.

\section{Литература}

1. Байденко В. И. Выявление состава компетенций выпускника вуза / В. И. Байденко - М., 2001. - 72 с.

2. Бернс Р. Развитие Я - концепции и воспитание / Р. Бернс. - М., 1986. - C. 30-31.

3. Зимняя И. А. Исследовательская работа как специфический вид человеческой деятельности [Текст] / И. А. Зимняя, Е. И. Шашенкова. - М.: Исследовательский центр проблем качества подготовки специалиста, 2001. - С. 59-63.

4. Репета Л. М. Исследовательская деятельность как фактор формирования исследовательской компетенции учащихся [Электронный pecypc]. Режим доступа: http://www.teoria-practica.ru/-112012/pedagogics/repeta.pdf

5. Савенков А. И. Психологические основы исследовательского подхода к обучению / А. И. Савенков. - М. : «Ось - 89», 2006. - 480 с.

6. Шадриков В. Д. Введение в психологию: способности человека / В. Д. Шадриков. - М., 2002. - 160 с. 